ESJ Humanities

\title{
Kidnapped and Made Brides: Advancing Quantum Reparation for Sexual and Gender-based Victims in Conflict Zones
}

\author{
Olayinka Oluwakemi Adeniyi
}

OpenAIR/QEScholar, Research Fellow, Centre for Intellectual Property and Information Technology Law (CIPIT), Strathmore Law School, Strathmore

University, Nairobi, Kenya

CEO, Women on The Watch Society Initiative, South Africa

Doi:10.19044/esj.2021.v17n13p60

Submitted: 30 November 2020

Accepted: 12 February 2021

Published: 30 April 2021

\author{
Copyright 2021 Author(s) \\ Under Creative Commons BY-NC-ND \\ 4.0 OPEN ACCESS
}

Cite As:

Adeniyi O.O. (2021). Kidnapped and Made Brides: Advancing Quantum Reparation for Sexual and Gender-based Victims in Conflict Zones. European Scientific Journal, ESJ, 17(13), 60. https://doi.org/10.19044/esj.2021.v17n13p60

\section{Abstract}

Conflict is the friction resulting from incompatibilities among people. Conflict has become a common experience in many African countries today which has led to bloodshed, death, starvation, famine, and ravaged communities. In this scenario, women and children have always been the worst hit. The girl child, particularly, and women are sexually abused, raped, kidnapped, and sometimes converted to sex slaves or forced into marriages. Since 2009, Boko Haram, a group of notorious terrorists, has been operating in the Northern part of Nigeria. One major feature of the signage of the group is the abduction of girls and women whom they forced into sexual slavery and marriage. In the years following the onslaughts, many of these girls were returned based on negotiations with the Federal Government of Nigeria. Some of the girls were returned defiled, some with children, and some with pregnancies as evidences of their sex slavery experience in the hands of the insurgents and abductors. While the Boko Haram troop's attack is still an ongoing experience in Nigeria, little or nothing, however, is relayed about the issue of reparation for the girls and women returnees. Access to justice is one major factor that has not been provided for the victims. Using a desktop research, existing literature is reviewed in an analytical and comparative methodology, as available legal provisions are examined. It is suggested to the 
Nigerian government to involve the victims in the discourse of reparation and ensure their access to justice. This will ensure that quantum reparation is provided. The paper will be of immense importance to the Nigerian government, policymakers, civil organizations, human rights practitioners, the victims, as well as the citizenry. It will contribute in the way of education and policy making to the mentioned people.

Keywords: Reparation, conflict, child marriage, sexual abuse, Girl child, Africa, Boko Haram, Nigeria

\section{Introduction}

Conflict is a common phenomenon among people (Ovaga, 2012). Conflict is the reality of the situation in many countries particularly developing countries and in Nigeria in particular (Egbegi, Ajah \& Ogbonnaya, 2018). The causes of the conflict can be multiple. Many countries have experienced tribal or ethnic conflicts; some conflicts have been traced to religious fanatism, while some are the aftermaths of revolutions as citizens' response to bad leadership. Conflict-related sexual violence refers to incidents or patterns of sexual violence against women, men, and children that include rape, sexual slavery, forced prostitution, enforced sterilization, and other comparable acts, occurring in conflict or post-conflict settings (Gorris, 2015). It includes victims who are raped by soldiers in whose care they are at the camps. The term also encompasses trafficking in persons for sexual violence or exploitation, when committed in situations of conflict (Huve, 2018; UN, 2019).

From an international human rights perspective, sexual violence infringes on a large number of human rights, such as the right to life, the right to health, the right to bodily integrity, and, most often, as a violation of the prohibition on torture, inhumane and degrading treatment, or as a form of gender-based violence (Gorris, 2015). Sexual violence during conflict extends to violence also used as a tactic of terrorism in Nigeria, where women and girls were targeted for abduction and sexual abuse by extremist groups as part of their financial calculus and self-perpetuation. Conflict-related sexual violence does not exclude boys as victims (Gorris, 2015), but the focus of this paper is on girl victims and the Boko Haram terrorists' situation in Nigeria. The Boko Haram conflict situation which is argued as an Islamic religion undertone (Brinkel \& Ait-Hida, 2012) has resulted to the killings of both men and boys while the sexual assault victims, being mostly women and girls, are used as sex slaves or war brides. Thus, according to their religion, the Boko Haram soldiers believe that the sexual assault victims are their war booties. These women and girls are raped, assaulted, defiled, and forced into marriages or sexual slavery irrespective of their ages. States are expected to address these 
violations and even non-state actors are required to make specific commitments and implement action plans to prevent sexual violence. Also, this is the case for the victims who suffered violations in the hands of military or soldiers in the camps where they are kept for protection by the government. This scenario is nothing short of a situation of an internal conflict which involves gross human rights violation and sexual and gender-based violence. The Federal Government of Nigeria has severally deployed national armed troops to the affected communities for defence and security. Furthermore, the international communities have also given aids to some of the victims. Reparation is not an alien word in conflict issues. It has, however, become a relevant one for discourse in the issue of sexual assault or victims of sexual violence within conflict scenarios. Reparation refers to the process and result of remedying the damage or harm caused by an unlawful act (Walker, 2013). Reparative measures can either be in material or symbolic form and on an individual or collective basis (Walker, 2013). The purpose of reparation is generally understood to re-establish the situation that existed before the harm occurred. It can also serve as a measure to end on-going breaches and to deter future ones, as a vehicle for reconciliation or to restore relations between the violator and injured parties, as well as a basis to repair or rehabilitate physical and psychological integrity and dignity (UN, 2019). In international law, a breach of an international obligation gives rise to a duty to repair the harm caused.

In discussing the issue of reparation for the victims, especially, where uncountable or unquantifiable loss has occurred, like loss of virtue, chastity, honour, marriageability, future comfort, peace, or settled home, the quantum of the reparation is also necessary. Issues like the possibility of reparation, the form of reparation, the measure or adequacy of reparation, and the manner or method as laid down by legal framework possible still beg for attentions. Other issues that arise for consideration in the scenario relate to those whose responsibility or duty is to provide reparation; is it the national government, or the perpetrators, or the international communities, if any? What role should international and regional organizations play in the issue of reparation for these victims? Also, is there any existing precedence for reparation that can be used as a template?

There is the emerging acknowledgment that the state is responsible for providing justice for the victims of armed conflicts. These sustainable justices require judicial accountability, truth, and reparation (Evans, 2012). Using the case of the Nigerian girl victims of the Boko Haram terrorists, these and other challenges which are relevant within this discourse are what this paper seeks to discuss as it makes a call for the actuality of the realization of quantum reparation in the case of the Boko Haram sexual victims returnees. The paper is divided into seven (7) sections. It starts with the introduction, followed by 
the second section, which discusses the Boko Haram onslaughts in Nigeria and its effects. The third section discusses the various forms of reparation, and who should provide them. The fourth section discusses the legal framework on conflict and reparation for victims. The Fifth section provides a case study of the Chibok girls and the reparation made available to them. The sixth section discusses the issue of the measure of the adequacy and challenges of reparation in sexual abuse cases. The seventh section provides the conclusion and recommendations to reaching adequate reparation for sexual abuse victims of conflict.

\section{The Boko Haram Onslaughts in Nigeria and its Effect}

Boko Haram is the nickname for "The Association of the Sunnah People for Proselytization and Armed Struggle" (Higazi, 2013). The rise of Boko Haram attacks in Nigeria can be traced to 2011(Cook, 2011) although it has been in existence since around 2002 (Mohammed, 2018). Since then, they have carried out various attacks, particularly, in the northern part of the country. Boko Haram is an Islamic militant group based in Nigeria's northwestern states of Yobe and Borno, although they have extended beyond these states now. It is said that their original intent was to "purify Islam in northern Nigeria" (Agbiboa, 2013).

The activities of Boko Haram have contributed serious threat to the country, not just physically but in the area of security, economy, and others (Ovaga, 2012). Wanton destruction of lives and wastage of properties has been its insignia (Chukwurah et al., 2015). Killings of humans in the most terrible manner have marked their passing (Onuaohah et al., 2014). Bombings, including self-bombing, ambush, kidnaps, drive-by shootings, and the worst manner of killings have been perpetrated by this group in many states of the country (Njoku \& Nwachukwu, 2015). The group has also consistently attacked a variety of targets including Christians (Shimawua et al., 2016), security agents, traditional rulers, politicians, school children and teachers, Islamic scholars, public servants, traders, and lately all non-members of the group.

There is no exact figure on the death toll caused by Boko Haram attacks. However, it was claimed in May 2014 that since 2009, the group has killed over 12,000 Nigerians and injured over 8,000. The group is known for killing boys and men while girls and women are raped, sexually assaulted, and forced into marriage or turned into sex slaves (BBC, 2019). According to the New York Times (2017), an estimate of up to 9,000 women and girls have been abducted since the start of Boko Haram's insurgency; at least 13,000 more are unaccounted, and likely even more from areas that are too dangerous to assess. Boko Haram militants kidnap and rape young girls, teenagers, and women, and engage them as child brides (New York Times, 2017). Under 
these occurrences, these girls and women can be properly described as victims of sexual and gender-based abuse in conflict zones albeit within their own country.

Notable of the attacks of this Boko Haram group which relates to sexual and gender-based abuse is the attack on the Girls' Government boarding school in Chibok, Borno State, where the group kidnapped over 200 female students (Pacific Standard, 2019). The leader of the group claimed that the girls were abducted by members of his group and threatened to sell them under their religious practice (BBC News, 2014). The abduction attracted serious local and international outcry, compelling countries such as the United States, the United Kingdom, France, China, and Israel to offer various kinds of supports to Nigeria.

The impacts of the onslaughts of Boko Haram and its effects, particularly, on the issue of sexual abuse of girls have necessitated this discourse on the issue of reparation. When damage or harm has been perpetrated on citizens by the acts of terrorists, it is expedient that there ought to be a redress, justice, or a form of damages to compensate victims.

\section{Forms of Reparation and Who Should Provide It}

When a victim gets a redress, justice, or a form of damage to compensate for the loss suffered, a term to capture it is reparation. Most times, the word "reparation" goes along with rehabilitation. "Reparation and rehabilitation" are words to describe what can be done to help victims overcome the damage that they suffered, to give them back their dignity, and to make sure that these abuses do not happen again (General Comment 31, Human Rights Committee).

Reparation could take many forms which include money, but a financial payment is not the only form of reparation and rehabilitation (General comment 3, Committee against Torture). Reparation can involve restitution, rehabilitation, public apologies, guarantees of non-repetition and changes in relevant laws and practices, as well as access to justice (General comment 3, Committee against torture).

Reparative measures can either be in material or symbolic form which can be given to an individual or a group on a collective basis. Measures such as restitution, compensation, or monetary benefits for damages and rehabilitation which could be medical, legal, and psychosocial are forms of reparation. Acknowledgment of wrongdoing, apology, decent re-burials of the dead, construction of memorials, and guarantees of non-repetition are also forms of reparation (Carranza, Correa, \& Naughton, 2015)

Reform of laws and the reform of civil and political structures too in response to loss or damage suffered can also be a form of reparation. 
Restitution is about the reestablishment of the situation that existed before the wrongful act was committed (Jacob, 1970). Compensation relates to any pecuniary and non-pecuniary losses, including loss of profits and employment. Rehabilitation refers to long-term medical and psychological care and surgeries as well as legal care (Patel, 2019), whereas satisfaction refers to measures such as formal acknowledgment of the unlawful character of the breach, apologies, and prosecutions (Dumberry, 2012). Reintegration and provision of therapy can also be methods of reparation.

Guarantees of non-repetition are forward-looking remedies focusing on prevention that can refer to either measure of deterrence aimed at protecting a victim from further harm or broader measures (Shala, 2018). Reparations are one of several transitional justice mechanisms that should be implemented holistically in a manner that fosters mutual reinforcement.

To this end, it is the view that reparation programs should be closely linked to other transitional justice or redress initiatives, like criminal justice, truth-telling, and institutional reform. What this means is that access to justice should be part of the reparation program. This way, reparation will be beneficial in terms of justice, way beyond the mere exchange of money and services for appeasement or acquiesce. The long-term benefit of such an approach is that there can be a marked improvement in the overall perception of the reparation measures adopted.

\subsection{Who Should Provide Reparation?}

Having discussed the forms of reparation and the fact that victims should be entitled to reparation, being an issue of general understanding (Manjoo, 2017), the next relevant discourse should be whose responsibility is it to provide reparation for the victims? General discussions on the issue of reparation present parties that appear in the scene as the perpetrators, government, local communities, international communities, nongovernmental organizations, and others. The party commonly ascribed with the responsibility of the protection and provision of reparation for victims of conflict-related sexual abuse is the government (Henry et al., 2013). This government would usually be the government of the state where the conflict is ongoing and where the crime was perpetrated. At other times, the person or group or individual responsible for the harm should provide reparation, especially when it takes the form of apologies or acknowledgment of wrongdoing. Even at this, government or state can tender an apology for failing to protect the harmed victims. The state can also by capturing the insurgence make them admit their wrong and tender apologies. At any rate, the state has the obligation for reparation (Labenski, 2020). Again, the government has the support of international communities through various NGOs to provide reparation. States are therefore obliged to provide reparation. 
Generally, being an issue of rights that has to do with right holders and duty providers, states are saddled with the duty of providing reparation (Evans, 2012). However, as with all international human rights provisions, the legal framework is the agreement or treaty that is binding between states.

\section{The Legal Framework on Conflict and Reparation for Victims}

As a general background, the legal framework for reparation of victims and conflict can be found within international, regional, and domestic provisions.

\subsection{International Framework}

The international legal basis for the right to a remedy and reparation can be found enshrined in the body of international human rights instruments, international humanitarian law (IHL), International Criminal Law, or International Criminal Court provisions (Gorris, 2015). Some provisions can be said to provide for protection against or prohibitions of sexual slavery, prostitution, and sexual abuse of rape and related offenses during the conflict. Conflict-related sexual violence has come to gain recognition as an international crime. Being a crime that inflicts torture on its victims, it can be argued to be prohibited within the provisions of the UN General Assembly (UNGA Resolution 217A, Convention against Torture). Other times, these prohibitions or protection can be gleaned from general instruments (UNDR) or specific instruments provided for the protection of women (CEDAW) and children (UNCRC). The Declaration on the Elimination of Violence against Women is also relevant (DEVAW 1993).

Provisions on a right to a remedy for victims of violations of international human rights law are found in the Universal Declaration of Human Rights (Art 8), the Convention on the Elimination of all Discrimination against Women (CEDW) (General Recommendation 35). The Declaration on the Elimination of Violence against Women (1993) places a duty on the state to prevent, investigate, punish, and provide compensation for all acts of violence wherever they occur. The Declaration states that women who are subjected to violence should be informed and provided with access to mechanisms of justice and to just and effective remedies for the harm that they have suffered, as provided by national legislation (Art 4 Devaw), International Covenant on Civil and Political Rights (Art 2), the International Convention on the Elimination of All Forms of Racial Discrimination (Art 6), the Convention against Torture and Other Cruel, Inhuman or Degrading Treatment or Punishment (Art 14), the Convention on the Rights of the Child (Art 39), and the International Convention for the Protection of All Persons from Enforced Disappearances (Art 24). 
The obligation to make reparation in cases of violations of international humanitarian law is reflected in The Hague Convention respecting the Laws and Customs of War on Land of October 18, 1907 (Convention IV) (Art 3), and the Protocol Additional to the Geneva Conventions of 12 August, 1949 (Art 91). The Rome Statute for the International Criminal Court also incorporates the rights to reparation of victims of crimes under the jurisdiction of the Court (Art 7(1)(g)). Reparation for breaches of international obligations can also be made by a State to another State, an international organization to a State, or an international organization to another.

The Geneva Convention has also been a provision relating to the protection of civilian persons in times of war. The UN and Beijing Declaration and Platform for Action (1995) included the protection of women and girls during armed conflict. From an international policy perspective, UN Security Council Resolution 1325 (2000) framed for the first-time sexual violence as a tactic of war and a threat to international peace and security (Gorris, 2015). This drew attention to violence against women during conflict and makes provision for reparation. Eight subsequent resolutions on women's peace and security affirm the UN commitment to combat Conflict-Related Sexual Violence. The guidance note of the Secretary-General on reparations for conflict-related sexual violence (2014) provides the UN Basic Principles with the Right to a Remedy and Reparation for Victims of Gross Violations of International Human Rights Law and Serious Violation of International Humanitarian Law (the UN Basic Principles). Thus, this was adopted in 2005 (A/RES/60/147). This provides victims the right to equal and effective access to justice including the right to adequate, effective, and prompt reparation for harm suffered and access to relevant information concerning violations and reparation mechanisms (UNGA Resolution).

UNSCR 2467 calls for a more holistic understanding of justice and accountability which includes the provision of reparations for survivors as well as livelihood support to enable them rebuild their lives and support their families, including the children born out of sexual violence in conflict (S/RES/2467).

\subsection{African Region-Specific Framework}

The provisions that can amount to provision for reparation for victims can also be found in some regional instruments. Art 7 of the African Charter on Human and Peoples' Rights, Art 25 of the American Convention on Human Rights, and Art 13 of the Convention for the Protection of Human Rights and Fundamental Freedoms are examples.

African Charter on Human and Peoples' Rights is also known as the Banjul Charter. It is a human rights instrument that is intended to promote and 
protect human rights and basic freedoms in the African continent. It Prohibits Torture and Cruel, Inhuman and Degrading Treatment (Art 5). It provides the Right to Equality before the Law and Equal Protection of the Law (Art 3). The Protection of the Family and Vulnerable Groups is a provision within the instrument (Art18).

The African Charter has a protocol for women. The African Charter on Human and Peoples' Rights on the Rights of Women in Africa (the Maputo Protocol) also provides reparation (Art4, para 2).

\subsection{National Domestic Framework}

For Nigeria, being a treaty to International and Regional human rights instruments, the provisions relating to the provision of reparation can be assessed. This is because the protocols and laws needed to make reparation accessible to victims are already in place. Nigeria has also ratified the Convention on the Elimination of All Forms of Discrimination against Women (CEDAW), the Protocol to the African Charter on Human and Peoples' Rights on the Rights of Women in Africa (Art 11, Maputo Protocol), and have enacted the Child Rights Act (CRA) and the Violence Against Persons Prohibition (VAPP) Act. It is important to mention that ratified instruments are subject to the constitutional provision in section 12 of the Nigerian constitution. The section states that "No treaty between the Federation and any other country shall have the force of law to the extent to which any such treaty has been enacted into law by the National Assembly" (S12 (1) CFRN 1999). The African Charter on human and peoples' rights has been domesticated in Nigeria.

Apart from treaties and national legislation which entrench the treaties, a core strategic objective under Pillar 3 of Nigeria's second National Action Plan (2017-2020) for the Implementation of UNSCR 1325 and related resolutions is the protection of women's and girls' rights and security and prosecution of violators of such rights (CFR, 2018). The provisions of the Terrorism (Prevention) (Amendment) Act, 2013, on the issue of protection of citizens and provision of reparation is also relevant.

As a human rights issue, the state government must ensure that victims receive reparation for the harm done to them. It is trite that most state governments receive support and aids from international bodies, organizations, and civil society actors to accomplish these (S/RES/2467). From this, it can be implied that the Nigerian government is under the obligation to provide reparation for the victims of sexual abuse and in this case, the Chibok girls who were kidnapped and made brides by the Boko Haram insurgents are entitled to reparation. 


\section{The Case Study: The Chibok Girls}

From the report in Nigeria, of the victims interviewed, only some of the Chibok students who escaped from Boko Haram captivity have received limited counselling and medical care. None of the other victims of abduction or other violations, all from desperately poor families, had received or were aware of any government-supported mental health or medical care (Human Rights Watch, 2014). The federal and state funds, set up with supports from international agencies and foreign governments in the wake of the high-profile Chibok abductions, have targeted the escaped Chibok girls. There are varying degrees of screening and reintegration support programs. A rehabilitation program through a pilot program in 2016 called the Safe House in Maiduguri was provided. Women were received for a period of about sixteen months, and they were given psycho-social supports, skills training, and lessons in what the state called "moderate Islam" and therapy designed to make them reject Boko Haram's violence and intolerance. The program was however not successful as most of the women returned to the insurgents by 2018 (International Crisis Group, 2019).

As for the case of the Chibok girls, kidnapped in April 2014, the girls who had spent 30-37 months in Boko Haram camp were released alongside other kidnapped women in late May 2017 (Brookings, 2017). The report has it that no one has been prosecuted for the sexual violence perpetrated against them (CFR, 2018). Some of these victims received assistance through government de-radicalization programs. At least 20 of the girls who escaped from Boko Haram have moved to the US to continue their education. The remaining girls may have been forced to integrate with Boko Haram, some may be ashamed to return home because they were forced to marry the fighters and have babies (Aljazeera, 2019). The girls, who would need medical treatment and psychological therapy, were said to have been placed in a rehabilitation centre in Abuja (VOA, 2017). Some of the returned girls are said to be undergoing a special course at the American University of Nigeria (AUN), Yola with their education funded by the government (VOA, 2018). The students, ages 17 to 19 , receive full scholarships covering tuition, room and board, books, and laptops. Their intensive academics encompass mathematics, science, and the arts. They have Friday pizza nights and weekend karaoke sessions. They also have ready access to a trauma counsellor (VOA, 2016). As of June of 2015 in Nigeria, 307 women and children were enrolled in a Government-run program to access counselling, education, and health care although remedies and reparations to the victims and accountability for the violations committed were recommended as of 2015 (OHCR, 2015).

In a bid to provide reparation, several projects have surfaced to work on the society and the victims in a way to help them get healed and reformed. 
Hamsatu Allamin has been working to change the narrative of "Boko Haram" (roughly translated as "education is a sin") to "Boko Halal" ("education is good"). One educational initiative underway is an Africa-America Institute plan to introduce a new digital learning tool in Nigeria and Ghana. She has also highlighted the need for a communication strategy to counter the influence of Boko Haram. Eleanor Nwadinobi has worked to increase the participation of women and girls in peace-building institutions by supporting safe spaces called "peace clubs." On the battleground, Aisha Bakari Gombi, also known as the "Queen Hunter," commands a band of male hunters and has helped the Nigerian military to fight Boko Haram and rescue hundreds of men, women, and children in northeast Nigeria. Apart from these, no known case of access to justice is seen to have been provided for the Chibok girls or any other victims of Boko Haram in Nigeria.

In comparison with other jurisdictions outside Nigeria, state governments include access to justice in their reparation measures. Congo's government has taken "unprecedented steps" including prosecuting highranking officers for sexual violence and paying reparations to survivors (Independent News, 2015).

Sierra Leone has also developed a National Action Plan on the resolution and monitoring by GNWP Sierra Leone through research, interview, etc.

\subsection{The Measure of the Adequacy of Reparation and the Challenges for Sexual Abuse Victims}

The measure of reparation is not provided within the legal framework, but rather what is provided or required by law is appropriate compensation (General comment 31, Human Rights Committee). Appropriate compensation, however, may include adequacy. Again, adequacy or sufficiency of reparation cannot be easily measured or ascertained, particularly when it comes to sexual abuse. Some pertinent questions are whether the extent of the trauma of the victim is measured for sufficient compensation. Also, can compensation be given in monetary or psychological terms? Is it possible that the victim is restored to her original status before the assault? In cases like these, the adequacy of the reparation should consist of a combination of different forms of reparation (OHCHR, 2014). While reparation is not only about restoration or compensation, knowledge of the fact that justice is served is a worthy consideration. Ensuring that reparations are just and adequate requires a full understanding of the gendered-nature and consequences of the harm suffered. Victims of conflict-related sexual abuse require reintegration into the society, and achieving this is part of reparation.

Counselling, education, therapy, and reintegration including financial supports were provided for the Chibok girls. Nonetheless, there is no record 
of access to justice in the name of prosecution of perpetrators. Research provides that victims of Boko haram sexual abuse complained that they did not have feedback on the prosecution of the perpetrators. Even though it is recommended that Judicial and/or administrative reparations should be available to victims of conflict-related sexual violence as part of their right to obtain prompt, adequate, and effective remedies (OHCHR, 2014), this alone is a pointer to the fact that access to justice can be a measure of the adequacy of reparation.

Again, reparation should include or involve meaningful participation and consultation of victims in the mapping, design, implementation, monitoring, and evaluation of reparations. This does not appear anywhere in the girls' reparation process. The Chibok girls complained that they were separated from their families, kept incommunicado, and were not involved in the reparation processes. From their complaints, they were not satisfied with the reparation provided. Consultations with victims are particularly important to hear and air their views on the specific nature of reparation. In a situation where victims are involved in the process and or acknowledge satisfaction even where the money is not given, this could constitute adequacy or sufficiency. Adequacy entails a combination of different forms of reparations, not just one or some, but must be several. At any rate, it has to do with the satisfaction of the victim and acknowledgment of it.

\section{The Challenges of Reparation in Sexual Abuse Cases}

Access to reparation for victims of sexual abuse in conflict situations has been fraught with many challenges (Manjoo, 2017). Inadequacy of a specific and clear legal framework is one challenge (Evans, 2012). No legally binding instrument that consolidates the rights of victims has been adopted (Evans, 2012).

To get reparation, there must be a process or procedure to assess the damages or hurt which requires hearing or trial. Reporting the incident by victims is generally, like all cases of sexual abuse, a challenge. Most survivors of conflict-related sexual violence face daunting social and structural reporting barriers that prevent their cases from being counted, much less addressed (Brookings, 2017).

Resources can be a challenge to reparation and poverty is one problem of many African countries (Brookings, 2017). Lack of institutions is also a challenge. For example, although these cases can be handled as human rights cases, the regular courts are already overburdened with regular cases than to veer into cases of insurgent sexual abuse of victims (Evans, 2012). Moreover, cases of acts of insurgents and abuse of human rights will, many times, require specialized courts or tribunals. In this case, lack of specified system of eligibility and the requirement of large resources for reparation can be a 
challenge also (Brookings, 2017). Some other challenges are access to survivors due to many reasons, suspicion of researchers, heavy security presence, and the on-going insurgence (Open Democracy, 2019). The cost of the reintegration program is also a challenge (International Crisis Group, 2019). Victims may not show up to receive help or reparation because of stigma, shame, not knowing about the directorate, and logistical barriers such as travel time and cost (Open Democracy, 2019).

In the case of Nigeria, one challenge is the non-domestication of the Convention on the Elimination of Discrimination Against Women (CEDAW) despite ratification which affects its implementation. Again, trials under the Terrorism (Prevention) (Amendment) Act, 2013, do not consider sexual violence crimes. For the Chibok girls' case, it is argued that a lot of politicization is behind the issue. Some factors difficult to reveal will not permit the government to prosecute the perpetrators of the sexual abuse thus preventing the girls from having access to justice. Inadequate understanding of reparation by government officials and cultural perceptions are also challenges to the girls receiving reparation and receiving adequate reparation for that matter.

\section{Conclusion and Recommendations}

For the general conflict-based sexual abuse victims in Nigeria, there are evidences of reparation and supports from the government. Recovery houses and rehabilitation programs are provided to reintegrate victims into the society. Although challenges abound, the situation is not one that is void of reparation programs. One major lacking area is access to justice which is germane to the reparation process and would in a way measure the adequacy of the reparation. While it is trite that sexual and gender-based violence is rarely reported owing to the fear of stigmatization and prevailing cultural beliefs, the Boko Haram insurgency is notorious for forced marriages and sexual exploitation of the victims. Thus, there ought to be a plan for their prosecution. For the Boko Haram girl sexual abuse victims, an extent of reparation has been made but it is not holistic and can be said not to be in line with the provisions. This is because the victims are not reintegrated into their former society, not connected back to their families, and are not included in the planning and programming of the reparation. In addition to this is the fact that till date, there is no prosecution of the perpetrators. This clearly demonstrates the lack of access to justice. The government is encouraged to take a closer look at its reparation process and make room to include the girls in the process and reintegrate them with their families. The area of access to justice should also be looked at, and perpetrators must be brought to book. The Nigerian government is still a long way from fulfilling its obligations on reparation for the girl victims of the Boko haram conflict situation. The 
experience of the girls can be described as that of conflict-based sexual abuse. Most of the young girls were forced into marriages with the insurgents. Some of the girls were with pregnancies, even some with babies, as at the time of their returns. In the way of reparation, the Nigerian government was able to provide help to the girls, special education and training, housing or accommodation, or resettlement. Several things were done for the girls except the access to justice, particularly in prosecuting their offenders. Since there are no ways to measure the adequacy of reparation in the case of sexual abuse, access to justice should be of utmost importance in order to complete the process of reparation and satisfy the victims even if they still bear the scars and memories of the abuse. Adequacy of reparation for this type of abuse may be difficult to assess or provide. It is possible that involving the victims in the reparation might bring satisfaction to them. The question as to whether this will be lawful, since the victims are minors and not legal minded, is another setback. However, it can be argued that it is only when victims can testify that they have been given access to justice that reparation can be said to have been truly provided. While the attempts of the Nigerian government at providing an extent of reparation is acknowledged, efforts to work on the area of providing access to justice and involving victims in the process is encouraged.

\section{References:}

1. Agbiboa, D. (2013). The ongoing campaign of terror in Nigeria: Boko Haram versus the state. Stability: International Journal of Security and Development, 2(3).

2. BBC News (2014). "Boko Haram 'to sell' Nigeria girls abducted from Chibok" BBC News 5 May at https://www.bbc.com/news/worldafrica-27283383 accessed 6 Nov 2019.

3. BBC News (2019). "Dem rape me and marry me out three times to Boko Haram members" - victim BBC News Pidgin 28 June 2019 at https://www.bbc.com/pidgin/tori-48804979 accessed 1 August.

4. Brinkel, T., \& Ait-Hida, S. (2012). Boko Haram and jihad in Nigeria. Scientia Militaria: South African Journal of Military Studies, 40(2), 121.

5. Brookings (2017). "Order from chaos Under the hot Sahel sun: "Post"Boko Haram challenges in Niger and Nigeria" June 8, 2017, at https://www.brookings.edu/blog/order-from-chaos/2017/06/08/underthe-hot-sahel-sun-post-boko-haram-challenges-in-niger-and-nigeria/ accessed 28 Oct 2019

6. Carranza, R., Correa, C., \& Naughton, E. (2015). "More Than Words -Apologies as a Form of Reparation" International Center for Transitional Justice 
7. Chukwurah, D. C., Okechukwu, E., \& Ogbeje, E. N. (2015). The implication of Boko Haram terrorism on northern Nigeria. Mediterranean Journal of Social Sciences, 6(3), 371-371.

8. Conflict Related Sexual Violence report of the United Nations secretary-general S/2019/280 29 March 2019.

9. Cook, D. (2011). The Rise of Boko Haram in Nigeria. CTC Sentinel, 4(9), 3-5

10. Council of Foreign Relations "from Africa in Transition Boko Haram's Violence Against Women and Girls Demands Justice" council on foreign relations May 11, 2018, at https://www.cfr.org/blog/bokoharams-violence-against-women-and-girls-demands-justice accessed on 28 Oct 2019

11. Dumberry, P (2012). Satisfaction as a Form of Reparation for Moral Damages Suffered by Investors and Respondent States in InvestorState Arbitration Disputes Journal of International Dispute Settlement, Volume 3, Issue 1, Pages 205-242, https://doi.org/10.1093/jnlids/idr016

12. Egbegi, F. R., Ajah, B. O., \& Ogbonnaya, C. (2018). Combating boko haram insurgency through a superior ideology: the role of the federal government. European Journal of Political Science Studies, Volume 1 , Issue 2, pages 13-22.

13. Evans, C. (2012). The right to reparation in international law for victims of armed conflict (No. 91). Cambridge University Press.

14. Gorris, E. A. P. (2015). Invisible victims? Where are male victims of conflict-related sexual violence in international law and policy? European Journal of Women's Studies, 22(4), 412-427

15. Guensburg, C (2019). "Why captured chibok schoolgirls can't always go home again" VOA May 20, 2016, at https://www.voanews.com/africa/why-captured-chibok-schoolgirlscant-always-go-home-again accessed 30 Oct.

16. Guidance Note of the Secretary-General (2014). Reparations for Conflict-Related Sexual Violence June at https://www.ohchr.org/Documents/Press/GuidanceNoteReparationsJu ne-2014.pdf accessed 6 Nov 2019.

17. Henry, S., Rizvi, F., \& Tchoukleva, I. (2013). Promoting Accountability for Conflict-related Sexual Violence against Men: A Comparative Legal Analysis of International and Domestic Laws Relating to IDP and Refugee Men in Uganda. Refugee Law Project Working Paper, 24.

18. Higazi, A. (2013). The origins and transformation of the Boko Haram insurgency in northern Nigeria. Politique africaine, (2), 137-164. 
19. Human Rights Watch (2014). "Those Terrible Weeks in Their Camp" Boko Haram Violence against Women and Girls in Northeast Nigeria Human Rights Watch Oct 27, 2014, at https://www.hrw.org/report/2014/10/27/those-terrible-weeks-theircamp/boko-haram-violence-against-women-and-girls accessed 28 Oct 2019

20. Huvé, S. (2018). The Use of UN Sanctions to Address ConflictRelated Sexual Violence. Policy Brief, Washington DC: Georgetown Institute for Women, Peace, and Security.

21. International Crisis Group (2019). "Returning from the Land of Jihad: The Fate of Women Associated with Boko Haram" International Crisis Group Report No 275 / Africa 21 May at https://www.crisisgroup.org/africa/west-africa/nigeria/275-returningland-jihad-fate-women-associated-boko-haram accessed 28 Oct 2019.

22. Jacob, BR. (1970). Reparation or Restitution by the Criminal Offender to His Victim: Applicability of an Ancient Concept in the Modern Correctional Process, 61 J. Crim. L. Criminology \& Police Sci. 152

23. Labenski, S. (2020). Countering Conflict-Related Sexual and GenderBased Violence through Reparations. LSE Law-Policy Briefing Paper, (42).

24. Manjoo, R. (2017). Introduction: reflections on the concept and implementation of transformative reparations. The International Journal of Human Rights, 21:9, 1193-1203, DOI: 10.1080/13642987.2017.1366666

25. Mbah, F (2019). "Nigeria's Chibok schoolgirls: Five years on, 112 still missing Aljazeera" 14 April at https://www.aljazeera.com/news/2019/04/nigeria-chibok-schoolgirls-years-112-missing-190413192517739.html accessed 30 Oct 2019

26. Mohammed, K. (2018). The Origins of Boko Haram. In The Oxford Handbook of Nigerian Politics. Oxford University Press.

27. New York Times (2017). "They fled Boko Haram, only to be raped by Nigeria's security forces" New York Times Dec 8, at https://www.nytimes.com/2017/12/08/world/africa/boko-haramnigeria-security-forces-rape.html.

28. New York Times (2017). "Exposures Child, Bride, Mother: Nigeria" The New York Times Sunday Review JAN. 27, at https://www.nytimes.com/interactive/2017/01/27/sundayreview/29Exposures-child-bride-interactive.html

29. Njoku, J. U., \& Nwachukwu, J. (2015). The effects of Boko Haram's insecurity on Nigeria's economy. AFRREV IJAH: An International Journal of Arts and Humanities, 4(3), 26-41. 
30. OHCHR "Boko Haram's path of destruction" United Nations Human Rights Office of the High Commissioner 29 Oct 2015 at https://www.ohchr.org/EN/NewsEvents/Pages/BokoHaramspathofdes truction.aspx accessed 28 Oct.

31. Onuoha, F. C. (2014). A danger not to Nigeria alone: Boko Haram's transnational reach and regional responses. Friedrich-Ebert-Stiftung, Abuja Nigeria

32. Open Democracy (2019). "Beyond trafficking and slavery Listening to the stories of Boko Haram's wives Boko Haram has abducted women and girls for use as maids, wives, and spies. Speaking to the survivors is not easy Open Democracy 17 July at https://www.opendemocracy.net/en/beyond-trafficking-andslavery/listening-to-the-stories-of-boko-harams-wives/ accessed 28 Oct 2019

33. Open Democracy (2019). "Beyond trafficking and slavery Links between conflict-related violence and peacetime practices: perspectives from Sierra Leone Sexual and gender-based violence in war doesn't stop when peace comes". Open Democracy 3 July 2019 https://www.opendemocracy.net/en/beyond-trafficking-andslavery/links-between-conflict-related-violence-and-peace-timepractices-perspectives-sierra-leone/ accessed 28 Oct 2019.

34. Ovaga, O. H. (2012). The Socio-Economic Implications of BookHaram Activities in Northern Nigeria. Review of Public Administration \& Management, 1(2), 19-37.

35. Pacific Standard (2019). "The True Story of the Nigerian Schoolgirls Who Survived Boko Haram" Pacific Standard July 10, at https://psmag.com/ideas/the-true-story-of-the-nigerian-schoolgirlswho-survived-boko-haram accessed on 06 Nov 2019.

36. Patel, N. (2019). Conceptualising rehabilitation as reparation for torture survivors: a clinical perspective The International Journal of Human Rights, 23:9, 1546-1568, DOI:

$10.1080 / 13642987.2019 .1612373$

37. Shala, N. (2018). "Guarantees of Non-Repetition for Violation of Human Rights." Ph.D. thesis, Graduate Institute of International and Development Studies.

38. Shimawua, D., Victor, I., \& Asue, D. (2016). Assessing the Impact of Boko Haram Attacks on Christians in Nigeria. International Journal of Arts \& Sciences, 9(3), 217.

39. United Nations General Assembly Resolution (2005). Basic Principles and Guidelines on the Right to a Remedy and Reparation for Victims of Gross Violations of International Human Rights Law and Serious Violations of International Humanitarian Law, U.N. 
Doc.A/RES/60/147, $16 \quad$ December $2005 \quad 11$ http://www.ohchr.org/EN/ProfessionalInterest/Pages/RemedyAndRe paration.aspx

40. VOA (2019). "Chibok Girls Changed by Shame, Stockholm Syndrome VOA Jan 18, 2018, at https://www.voanews.com/africa/chibok-girlschanged-shame-stockholm-syndrome accessed 30 Oct.

41. VOA (2019). "More Than 100 'Chibok Girls' Restart Education in Nigeria" VOA September 20, 2017, at https://www.voanews.com/africa/more-100-chibok-girls-restarteducation-nigeria accessed 30 Oct.

42. Walker, M.U. (2013). The Expressive Burden of Reparations: Putting Meaning into Money, Words, and Things. In: MacLachlan A., Speight A. (eds) Justice, Responsibility and Reconciliation in the Wake of Conflict. Boston Studies in Philosophy, Religion and Public Life, vol 1. Springer, Dordrecht. https://doi.org/10.1007/978-94-007-52016_12

43. Withnall, Adam (2015). "One year on from Chibok girl kidnappings, UN identifies 19 countries where sexual abuse of both boys and girls has become a way of life" Independent 14 April at https://www.independent.co.uk/news/world/politics/kidnappednigeria-schoolgirls-one-year-on-un-identifies-19-countries-wheresexual-abuse-of-both-boys-10175379.html accessed 28 Oct 2019. 